\title{
AGRO-ECONOMIC INDICATORS FOR CARROT UNDER GREEN MANURE IN A SEMI-ARID ENVIRONMENT ${ }^{1}$
}

\author{
JOSIMAR NOGUEORA DA SILVA², FRANCISCO BEZERRA NETO ${ }^{3}$, JAILMA SUERDA SILVA DE LIMA ${ }^{3}$, \\ ARIDÊNIA PEIXOTO CHAVES ${ }^{3}$, ELIZÂNGELA CABRAL DOS SANTOS ${ }^{3}$, RENATO LEANDRO COSTA NUNES ${ }^{4} *$
}

\begin{abstract}
Green manuring is an important management strategy in tuberous vegetable production systems, since it improves the physical, chemical and biological properties of the soil and, consequently, increases in crop productivity and ecosystem balance. The objective of this work was to evaluate the agroeconomic efficiency of carrot cultivation as a function of Calotropis procera biomass amounts incorporated into the soil during two growing seasons in a semiarid environment. The experiments were conducted in an experimental design of randomized complete blocks, with four treatments and five replications. The treatments consisted of four C. procera biomass amounts $\left(20,35,50\right.$ and $\left.65 \mathrm{t} \mathrm{ha}^{-1}\right)$ incorporated into the soil. In each experiment, one plot with carrot without fertilization (control) was planted, for the purpose of comparison. The characteristics evaluated in the carrot were productivities of total and commercial roots, classified productivity of roots and production economic indicators. The maximum productivity of carrot roots of $35.90 \mathrm{t} \mathrm{ha}^{-1} \mathrm{was}^{-}$ possible with the incorporation of $47.60 \mathrm{t} \mathrm{ha}^{-1}$ of $C$. procera biomass into the soil. The maximum net income of $\mathrm{R} \$ 33.744,07 \mathrm{ha}^{-1}$ in the cultivation of this vegetable it was achieved with the addition of the C. procera biomass amount to the soil of $42.81 \mathrm{t} \mathrm{ha}^{-1}$. The return rates obtained for the carrot cultivation in these optimized quantities were 1.53 and 1.28, respectively, of those achieved in the control treatment (without fertilization).
\end{abstract}

Keywords: Calotropis procera. Classified productivity of roots. Daucus carota. Maximum physical and economic efficiency.

\section{INDICADORES AGROECONÔMICOS DA CENOURA FERTILIZADA COM ADUBO VERDE EM AMBIENTE SEMIÁRIDO}

RESUMO - A adubação verde é uma importante estratégia de manejo em sistemas de produção de hortaliças tuberosas, pois melhora as propriedades físicas, químicas e biológicas do solo e, consequentemente, aumenta as produtividades das culturas e equilíbrio dos ecossistemas. O objetivo deste trabalho foi avaliar a eficiência agroeconômica do cultivo de cenoura em função de quantidades de biomassa de Calotropis procera incorporadas ao solo ao longo de duas estações de cultivos em ambiente semiárido. Os experimentos foram conduzidos em delineamento experimental de blocos ao acaso, com quatro tratamentos e cinco repetições. Os tratamentos consistiram de quatro quantidades de biomassa de $C$. procera $\left(20,35,50\right.$ e $\left.65 \mathrm{t} \mathrm{ha}^{-1}\right)$ incorporadas ao solo. Em cada experimento, foi plantada uma parcela de cenoura sem adubação (controle), para fins de comparação. As características avaliadas na cenoura foram produtividades de raízes total e comercial, produtividade de raízes classificadas e indicadores econômicos de produção. A produtividade máxima de raízes de cenoura de 35,90 $\mathrm{t} \mathrm{ha}^{-1}$ foi possível com a incorporação no solo de 47,60 tha ${ }^{-1}$ de biomassa de C. Procera. A renda líquida máxima de $\mathrm{R} \$ 33.744,07 \mathrm{ha}^{-1}$ no cultivo desta hortaliça foi alcançada com a adição da quantidade de biomassa ao solo de $42,81 \mathrm{t} \mathrm{ha}^{-1}$. As taxas de retorno obtidas para o cultivo de cenoura nessas quantidades otimizadas foram de 1,53 e 1,28, respectivamente, das alcançadas no tratamento controle (sem fertilização).

Palavras-chave: Calotropis procera. Produtividade classificada de raízes. Daucus carota. Máxima eficiência física e econômica.

\footnotetext{
${ }^{*}$ Corresponding author

${ }^{1}$ Received for publication in $05 / 06 / 2020$; accepted in 11/06/2020.

Paper extracted from the doctoral thesis work of the first author.

${ }^{2}$ Secretaria de Agricultura e Recursos Hídricos, Belém do Brejo do Cruz, PB, Brazil; josimar2160@hotmail. com - ORCID: 0000-00019508-5526.

${ }^{3}$ Department of Agronomic and Forestry Sciences, Universidade Federal Rural do Semi-Árido, Mossoró, RN, Brazil; bezerra@ufersa.edu.br _ ORCID: 0000-0001-9622-206X, jailma@ufersa.edu.br _ ORCID: 0000-0001-7584-592X, aridenia.peixoto@hotmail.com-ORCID: 0000-0002-2184-2536, elizangelacabral@ufersa.edu.br-ORCID: 0000-0002-7074-3147.

${ }^{4}$ Teaching Department, Instituto Federal de Educação, Ciência e Tecnologia do Ceará, Limoeiro do Norte, CE, Brazil; renatoleandro.ce@hotmail.com - ORCID: 0000-0001-5792-2442.
} 


\section{INTRODUCTION}

Vegetable production in organic systems represents one of the fastest growing agricultural sectors due to the desire to protect producer and consumer health and to preserve the environment (SEDIYAMA; SANTOS; LIMA, 2014). Thus, producers are adopting alternative production strategies based on producing healthy, competitive, and sustainable foods. One important alternative strategy involves appropriate management of organic material inputs that are available on producers' own properties or neighborhoods and using them as fertilizer. These fertilizers can promote increased crop productivity without the use of synthetic chemical inputs (BATISTA et al., 2013), which often raise production costs.

Some producers in the Brazilian Northeast are using spontaneous species from the Caatinga biome as green manures in their vegetable production systems, as a strategy to increase nutrient concentrations and the proportion of organic matter in their soils (BEZERRA NETO et al., 2014). This technique of fertilization constitutes an important economic alternative for the supply of nitrogen to crops since nitrogen fertilizers contribute significantly to the elevated production costs of many crops (OLIVEIRA et al., 2010).

Some of these spontaneous species with high biomass production potential are highlighted as a source of green manure to promote satisfactory crop yields. Among these species, the roostertree (Calotropis procera Ait. R. Br.) is a prime example (FAVACHO et al., 2017). This plant has an excellent $\mathrm{C}: \mathrm{N}$ ratio at around $25: 1$ and also has a chemical composition rich in other important macronutrients, including $\mathrm{N}, \mathrm{P}, \mathrm{K}, \mathrm{Ca}$, and $\mathrm{Mg}$ contents of $18.4,3.1$, $14.5,16.3$, and $13.5 \mathrm{~g} \mathrm{~kg}^{-1}$, respectively (NUNES et al., 2018).

Since roostertree is adapted to the edaphoclimatic conditions, it has high net primary production when grown in the region (LINHARES et al., 2012), yielding on average $1.0 \mathrm{t}$ dry matter per ha per cut at 70 days between cuts with only $150 \mathrm{~mm}$ of precipitation, or yielding $3 \mathrm{t}$ dry matter per ha per cut with a 120 day regrowth interval and thus allowing three annual yielding $9 \mathrm{t}$ dry matter per ha (EMPARN, 2004), making roostertree an ideal candidate crop to use for green manure.

In order to provide the baseline information necessary to exploit the potential of roostertree, a few studies have investigated its use as a green manure in the production of vegetables, such as cowpea (VIEIRA et al., 2018), lettuce (BATISTA et al., 2012) and arugula (SOUZA et al., 2015). One of the questions that has been raised by tuberose producers in the semi-arid region of northeastern Brazil is whether the spontaneous $C$. procera plant used as green manure would have the potential to increase the carrot's productive yield and its economic efficiency?

Trying to answer this question, the present research was carried out with the objective of evaluating the agro-economic efficiency of a carrot monocrop as a function of $C$. procera biomass amounts incorporated into the soil over two growing seasons in semi-arid conditions of Rio Grande do Norte state.

\section{MATERIALS AND METHODS}

Between July and October 2017 and 2018, two field experiments were carried out at different areas of the Rafael Fernandes Experimental Farm that is located in the Lagoinha district $20 \mathrm{~km}$ from the Mossoró municipality $(\mathrm{RN})$, Brazil $\left(5^{\circ} 11^{\prime} 31\right.$ "S, $37^{\circ} 20^{\prime} 40^{\prime \prime} \mathrm{W}, 18 \mathrm{~m}$ altitude). The soil at the experimental farm is classified as a typical Dystrophic Red Argisol (RÊGO et al., 2016). The climate in this region is BShw according to the Köppen classification. The region is dry and very hot, has a summer rainy season, has an average maximum temperature between 32.1 and $34.5^{\circ} \mathrm{C}$ and minimum average between 21.3 and $23.7^{\circ} \mathrm{C}$ in the coldest months of June and July, and has an average annual precipitation around $685.3 \mathrm{~mm}$ (NUNES et al., 2018). Average temperature and air relative humidity in the days after sowing the carrot crop during the two growing seasons are presented in Figure 1

The soil preparation consisted of mechanically cleaning the area with the aid of a tractor and coupled plow followed by furrowing and lifting of the beds. A solarization using transparent plastic of 30-micron 'Vulca Brilho Bril Fles' was carried out for 45 days before the incorporation of green manure into the soil to reduce the soil phytopathogen population that might affect crop productivity.

After solarization, soil samples were collected at depths of 0-20 cm. Samples were air dried, sieved to $2 \mathrm{~mm}$, processed, and analyzed in the Soil Chemistry and Fertility Laboratory of UFERSA (Table 1).

The experimental design was a randomized complete block with four treatments and five replicates. The treatments consisted of four amounts of $C$. procera biomass incorporated into the soil (20, 35,50 , and $65 \mathrm{tha}^{-1}$ on a dry basis) tested in the 2017 and 2018 growing seasons. In each experiment, one plot with carrot without fertilization (control) was planted, for the purpose of comparison with the average value of optimized physic efficiency maximum in each evaluated characteristic in the carrot as well as with the average value of the fertilized treatments. 

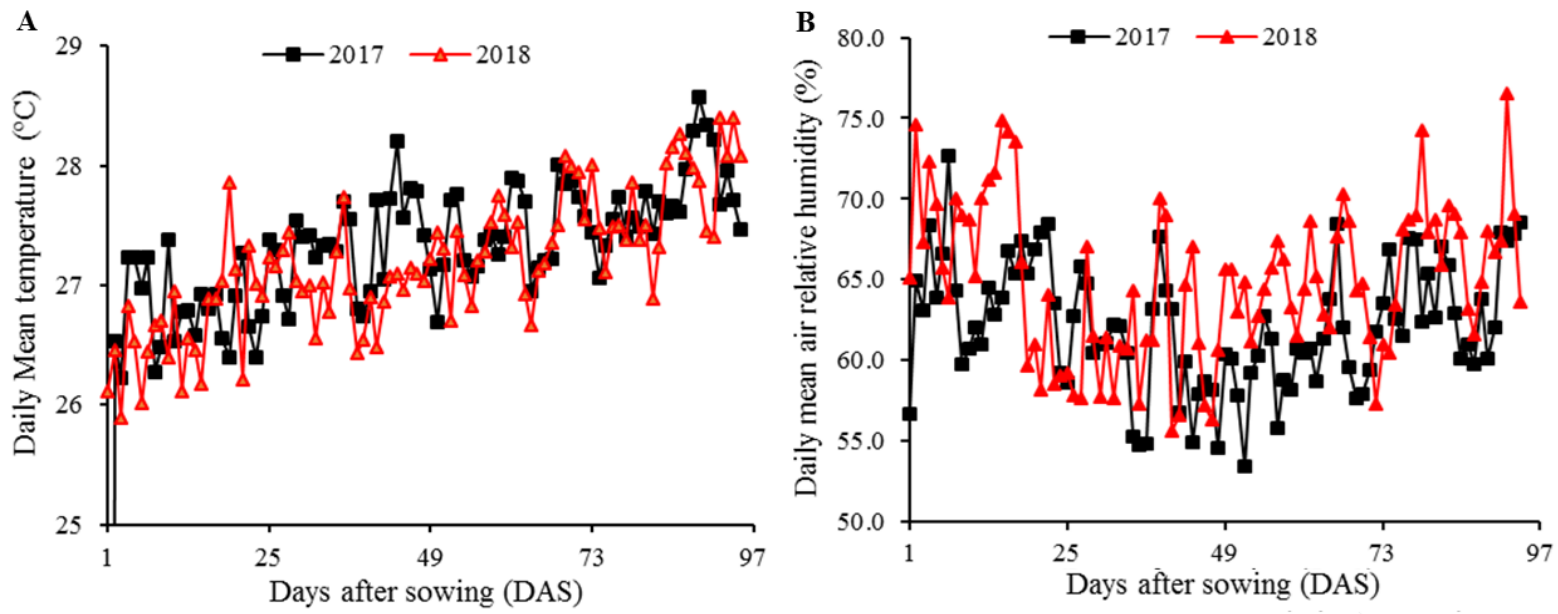

The carrot crop was sown on 24 July in 2017 and 2018

Figure 1. Daily mean temperature (A) and daily mean air relative humidity (B) in the days after sowing a carrot crop over two growing seasons.

Table 1. Chemical composition of soil samples from the experimental area over two growing seasons prior to the incorporation of $C$. procera.

\begin{tabular}{|c|c|c|c|c|c|c|c|c|c|c|c|c|c|}
\hline $\begin{array}{c}\text { Growing } \\
\text { seasons }\end{array}$ & $\begin{array}{c}\mathrm{N} \\
\mathrm{g} \mathrm{kg}^{-1}\end{array}$ & $\begin{array}{c}\mathrm{pH} \\
\text { (water) }\end{array}$ & $\begin{array}{c}\mathrm{EC} \\
\mathrm{dS} \mathrm{m}^{-1}\end{array}$ & $\begin{array}{l}\mathrm{OM} \\
\mathrm{g} \mathrm{kg}^{-1}\end{array}$ & P & $\begin{array}{c}\mathrm{K} \\
\mathrm{mg} \mathrm{dm}\end{array}$ & $\mathrm{Na}$ & & $\begin{array}{l}\mathrm{Mg} \\
\mathrm{dm}^{-3}\end{array}$ & $\mathrm{Cu}$ & $\begin{array}{l}\mathrm{Fe} \\
--\mathrm{m}\end{array}$ & $\begin{array}{l}\mathrm{Mn} \\
\mathrm{Im}^{-3}-\end{array}$ & $\mathrm{Zn}$ \\
\hline $1-2017$ & 0.51 & 7.46 & 1.77 & 3.64 & 63.30 & 60.0 & 17.00 & 2.09 & 0.58 & 0.19 & 2.03 & 10.43 & 6.21 \\
\hline $2-2018$ & 0.31 & 8.10 & 0.24 & 4.97 & 22.80 & 64.70 & 32.70 & 3.28 & 0.78 & 1.91 & 2.86 & 11.67 & 2.63 \\
\hline
\end{tabular}

$\mathrm{EC}$ is electrical conductivity and $\mathrm{OM}$ is organic matter.

Each experimental plot had dimensions of $1.20 \mathrm{~m}$ wide by $1.20 \mathrm{~m}$ long for a total area of 1.44 $\mathrm{m}^{2}$ and a harvested area of $0.80 \mathrm{~m}^{2}$. Plants were spaced at $0.20 \mathrm{~m} \times 0.10 \mathrm{~m}$ resulting in a 350.000 plants $\mathrm{ha}^{-1}$ population density, since $30 \%$ of 1 ha is of transit area, consisting of corridors and roads (MARTINS et al., 2018). The harvested portion of the plots consisted of the plants in central rows, excluding the first and last plant of each row and the side borders.

Calotropis procera was collected from natural stands in localities near the city of Mossoró aged between one and two years during the flowering period, when the plants have the highest concentrations of nutrients. The plants (branches and leaves) were cut at a soil height of $25 \mathrm{~cm}$ and crushed in a conventional forage machine to produce fragments between 2.0 and $3.0 \mathrm{~cm}$ long. Plant fragments were later submitted to a drying process in the open sun as suggested by a previous report (SOUZA et al., 2018). After drying, samples were submitted for laboratory analyses to establish their chemical composition (Table 2).

Table 2. Chemical composition of the $C$. procera in the first and second growing season.

\begin{tabular}{ccccccc}
\hline \multirow{2}{*}{ Growing seasons } & \multicolumn{7}{c}{ Green manure macronutrient content $\left(\mathrm{g} \mathrm{kg}^{-1}\right)$} \\
\cline { 2 - 7 } & $\mathrm{N}$ & $\mathrm{P}$ & $\mathrm{K}$ & $\mathrm{Ca}$ & $\mathrm{Mg}$ & $\mathrm{C}: \mathrm{N}$ \\
\hline $1-2017$ & 18.4 & 3.1 & 14.5 & 16.3 & 13.5 & $25: 1$ \\
$2-2018$ & 21.9 & 1.9 & 20.9 & 17.0 & 9.2 & $25: 1$ \\
\hline
\end{tabular}

$\mathrm{P}, \mathrm{K}$ and Na: extracted with Mehlich's solution; $\mathrm{Ca}$ and $\mathrm{Mg}$ : extracted with $\mathrm{KCl} \mathrm{mol} \mathrm{L}^{-1}$.

Fertilization was carried out in two stages. Thirty percent of the $C$. procera amount was incorporated 15 days before planting and the remaining seventy percent was incorporated 15 days after planting according to methodology suggested previously (SILVA et al., 2013).

Irrigations were carried out daily by microsprinkling in two irrigation shifts (morning and 
afternoon), providing an $8 \mathrm{~mm}$ blade per day. This procedure served the dual purposes of stimulating soil microbial activity to enhance decomposition of the organic fertilizer and meeting the crop water needs.

The crop grown was carrot (Daucus carota subsp. sativus) cv. Brasília that is recommended for the semi-arid condition of the Brazilian Northeast. Planting was carried out on July 24 in both growing seasons (2017 and 2018) by direct seeding at approximately $2.0 \mathrm{~cm}$ depth with three to four seeds per hole. In both years, thinning was performed 23 days after sowing, leaving one plant per hole. Weeding was performed manually whenever necessary.

Crops were harvested at 94 and 93 days after sowing (DAS) in the first and second growing seasons, respectively. Afterwards, the plants were transported to the Vegetable Post Harvest Laboratory of the Department of Plant Sciences at UFERSA where crop characteristics were evaluated. Dry mass of shoots and roots were measured, as were the total and commercial productivity of roots. The total productivity was composed of all roots of plot harvest area while the commercial productivity was of all roots free of cracks, bifurcations, nematode galls and mechanical damage. The total roots productivity was classified into long $(17-25 \mathrm{~cm}$ length and diameter $<5 \mathrm{~cm})$, medium $(12-17 \mathrm{~cm}$ length and diameter $>2.5 \mathrm{~cm})$, short $(5-12 \mathrm{~cm}$ length and diameter $>1 \mathrm{~cm}$ ), and scrap (roots that did not fit the previous measurements), according to Lana and Vieira (2000).

Economic efficiency indicators evaluated included gross income, net income, rate of return, and profit margin. The calculation of these parameters is presented below.

The cost of production was calculated and analyzed at the end of the production process for the two growing seasons and the total expenditure per hectare of cultivated area from each amount of $C$. procera added was analyzed. Revenues were obtained as the value from the production of one hectare that was measured, according to the price paid to the producer in October of 2017 and 2018. The price paid to producers for organic carrot was $\mathrm{R} \$ 1.80$ per $\mathrm{kg}$ in both growing seasons, coming from the average price of the last three years in the region (Table 3 ). The current exchange rate of the US\$ was $\$ 1=\mathrm{R} \$ 3.72$, in October 2018.

Gross income (GI) was obtained by multiplying the crop yield in each treatment by the value paid to the producer for the product, that is, $\mathrm{GI}=$ Yield $\mathrm{x}$ Price.

Net income (NI) was calculated by subtracting the total costs (TC) of inputs and services from gross income, that is, NI $=\mathrm{GI}-\mathrm{TC}$.

The rate of return (RR) was affected by the ratio between gross income and total cost, which corresponded to $\mathrm{R} \$$ obtained for each $\mathrm{R} \$$ applied. The expression is $\mathrm{RR}=\mathrm{GI} / \mathrm{TC}$.

The profit margin (PM) was obtained as the ratio between net income and gross income, expressed as a percentage (SILVA et al., 2017), that is, $\mathrm{PM}=(\mathrm{NI} / \mathrm{GI}) \times 100$.

Univariate analysis of variance was performed for each variable in each season to determine differences among $C$. procera tested amounts. A joint analysis over the two growing seasons was also carried out for each variable. Sisvar version 5.6 was used for analyses (FERREIRA, 2011). In order to perform this analysis, it was necessary that the residual mean squares of each variable evaluated did not differ substantively, that is, that they were relatively homogeneous or that the quotient between the largest and the smallest residual mean square was less than seven (PIMENTELGOMES; GARCIA, 2002). Tukey's post-hoc tests were used to compare means between the growing seasons. A procedure for adjusting regression curves with respect to variables was performed using Table Curve version 3.0 (JANDEL SCIENTIFIC, 1991) to estimate the response of each variable analyzed to the amount of $C$. procera biomass incorporated into the soil.

\section{RESULTS AND DISCUSSION}

\section{Performance of carrot culture}

No significant interaction was observed between the main effects of growing seasons and the amounts of $C$. procera biomass incorporated for any of the carrot crop characteristics evaluated. The main effect of growing season was significant for all carrot characteristics except for dry mass of roots and the productivities of medium and scrap roots (Table 3 ).

Shoot dry mass, total and commercial root productivity, and long root productivity were all greater in the first season. In contrast, the productivity of short roots was greater in the second cropping season (Table 3). This behavior may be related in part to soil $\mathrm{pH}$. According to Embrapa Hortaliças (2008), the exaggerated increase in $\mathrm{pH}$ can cause reductions in production. Ribeiro et al. (2020) reports that increase in productivity may also be related to the integration between the chemical characteristics of green manure and the $\mathrm{pH}$ of the soil close to neutrality. Another factor that may have caused this difference is related to the higher content of phosphorus (P) in the soil in the first growing season (Table 1). This nutrient has the function of stimulating rooting, as well as the fixation and stability of plants, and can provide greater productivity. 
J. N. SILVA et al.

Table 3. F values and means for dry mass of shoots (DMS) and roots (DMR), for total (TPR) and commercial productivity (CPR) of roots, and for classified productivity of long (PLR), medium (PMR), short (PSR) and scrap (PScR) roots of carrot over two growing seasons and for the control treatment and the maximum physical efficiency treatment (MPE).

\begin{tabular}{|c|c|c|c|c|c|c|c|c|}
\hline Sources of variation & $\begin{array}{l}\text { DMS } \\
\left(\mathrm{t} \mathrm{ha}^{-1}\right)\end{array}$ & $\begin{array}{l}\text { DMR } \\
\left(\mathrm{t} \mathrm{ha}^{-1}\right)\end{array}$ & $\begin{array}{c}\text { TPR } \\
\left(\mathrm{t} \mathrm{ha}^{-1}\right)\end{array}$ & $\begin{array}{c}\text { CPR } \\
\left(\mathrm{t} \mathrm{ha}^{-1}\right)\end{array}$ & $\begin{array}{c}\text { PLR } \\
\left(\mathrm{t} \mathrm{ha}^{-1}\right)\end{array}$ & $\begin{array}{l}\text { PMR } \\
\left(\mathrm{t} \mathrm{ha}^{-1}\right)\end{array}$ & $\begin{array}{c}\text { PSR } \\
\left(\mathrm{t} \mathrm{ha}^{-1}\right)\end{array}$ & $\begin{array}{l}\text { PScR } \\
\left(\mathrm{t} \mathrm{ha}^{-1}\right)\end{array}$ \\
\hline (Blocks/Seasons) & $2.32^{*}$ & $1.43^{\mathrm{ns}}$ & $1.77^{\mathrm{ns}}$ & $1.50^{\mathrm{ns}}$ & $4.47^{* *}$ & $0.92^{\mathrm{ns}}$ & $1.71^{\mathrm{ns}}$ & $1.00^{\mathrm{ns}}$ \\
\hline Growing seasons (S) & $8.87^{*}$ & $2.56^{\mathrm{ns}}$ & $53.80^{* *}$ & $48.95^{* *}$ & $88.73^{* *}$ & $3.04^{\mathrm{ns}}$ & $4.87^{*}$ & $0.77^{\mathrm{ns}}$ \\
\hline Amounts of C. procera (A) & $38.38^{* *}$ & $8.37^{* *}$ & $38.26^{* *}$ & $27.85^{* *}$ & $49.99^{* *}$ & $3.70^{*}$ & $9.05^{* *}$ & $1.63^{\mathrm{ns}}$ \\
\hline S x A & $0.63^{\mathrm{ns}}$ & $0.27^{\text {ns }}$ & $0.12^{\mathrm{ns}}$ & $0.43^{\mathrm{ns}}$ & $2.60^{\text {ns }}$ & $1.38^{\mathrm{ns}}$ & $2.38^{\mathrm{ns}}$ & $0.95^{\mathrm{ns}}$ \\
\hline Control vs factorial & $58.70^{* *}$ & $4.62^{*}$ & $7.00^{*}$ & $6.13^{*}$ & $8.03^{* *}$ & $0.60^{\mathrm{ns}}$ & $12.87^{* *}$ & $0.03^{\mathrm{ns}}$ \\
\hline CV $(\%)$ & 14.65 & 17.03 & 8.92 & 10.34 & 17.44 & 19.06 & 17.57 & 37.22 \\
\hline \multicolumn{9}{|l|}{ Growing seasons } \\
\hline 1 & $4.44 \mathrm{a}^{\dagger}$ & $2.98 \mathrm{a}$ & $35.00 \mathrm{a}$ & $33.60 \mathrm{a}$ & $21.08 \mathrm{a}$ & $11.28 \mathrm{a}$ & $1.24 \mathrm{~b}$ & $1.40 \mathrm{a}$ \\
\hline 2 & $3.81 \mathrm{~b}$ & $3.23 \mathrm{a}$ & $29.07 \mathrm{~b}$ & $27.31 \mathrm{~b}$ & $12.98 \mathrm{~b}$ & $12.57 \mathrm{a}$ & $1.76 \mathrm{a}$ & $1.76 \mathrm{a}$ \\
\hline \multicolumn{9}{|l|}{ Comparison treatments } \\
\hline Control & $1.67 \mathrm{~b}$ & $2.09 \mathrm{~b}$ & $21.96 \mathrm{~b}$ & $20.63 \mathrm{~b}$ & $3.57 \mathrm{~b}$ & $14.17 \mathrm{a}$ & $2.89 \mathrm{a}$ & $1.33 \mathrm{a}$ \\
\hline MPE treatment & $5.69 \mathrm{a}$ & $3.50 \mathrm{a}$ & $38.56 \mathrm{a}$ & $35.90 \mathrm{a}$ & $21.06 \mathrm{a}$ & $12.46 \mathrm{a}$ & $1.53 \mathrm{~b}$ & $2.30 \mathrm{a}$ \\
\hline
\end{tabular}

$* *=\mathrm{P}<0.01 ; *=\mathrm{P}<0.05 ; \mathrm{ns}=\mathrm{P} \geq 0.05 .{ }^{\dagger}$ Means followed by different lowercase letters in a column differ statistically from each other according to $\mathrm{F}$ test at the $5 \%$ probability level.

Phosphorus is especially importance in the initial growth stages of plants because it is used in energy storage and transfer processes and is directly involved in the active absorption of other nutrient (BRASIL; NASCIMENTO, 2010). When development occurs more rapidly, there is greater initiation and growth of leaves earlier in the crop cycle producing a larger foliar area that increases solar radiation interception and photoassimilate production (BONFIM-SILVA et al., 2011). In addition, $\mathrm{P}$ deficiency leads to shorter vegetative cycles because of poor stem development, and the invasive plants that are typical of poor soils with little P are favored (KROLOW et al., 2004), providing ultimately an environment with inadequate conditions for crop production.

The mean values of maximum physical efficiency (MPE) of the treatments that received fertilization differed from the control in all the agronomic characteristics of the carrot except for productivity of medium and scrap roots, where there was no significant difference between the means values of MPE and control (Table 3). In the production variables (total and commercial productivity of roots and productivity of long roots), the mean values of MPEs were, respectively, 1.8, 1.7 and 5.9 times the mean value of control treatment (Table 3). According to Nunes et al. (2018), the behavior related to growth and production variables in terms of maximum physical efficiency may be related to the environmental conditions to which the plants were exposed, resulting in a balance in the translocation of photoassimilates and their conversion.

The dry mass of shoots and roots took on a upward shape as a function of $C$. procera biomass added to the soil. Maximum carrot shoot and root dry mass (5.69 and $3.50 \mathrm{t} \mathrm{ha}^{-1}$, respecitively) were observed in the treatment with the greatest $\left(65.00 \mathrm{t} \mathrm{ha}^{-1}\right)$ C. procera biomass incorporated into the soil (Figure 2A). In this way we can infer that there was an accumulation of macro and micronutrients towards the carrot culture.

Total and commercial root productivities and carrot productivity classifications into long, medium, short, and scrap all responded to $C$. procera biomass additions in a polynomial manner such that the greatest productivities were found at intermediary $C$. procera biomass additions (Figure $2 \mathrm{~B}, 2 \mathrm{C}$, and $2 \mathrm{D}$ ). Maximum total and commercial root productivities were 38.56 and $35.90 \mathrm{t} \mathrm{ha}^{-1}$ when 47.32 and $47.60 \mathrm{t} \mathrm{ha}^{-1}$ of $C$. procera biomass were incorporated into the soil. Maximum long, medium, short, and scrap root productivities were $21.06,12.46,1.53$, and $2.30 \mathrm{t} \mathrm{ha}^{-1}$ when $C$. procera biomass was added to the soil at 53.15, 48.06, 40.95 and $45.92 \mathrm{t} \mathrm{ha}^{-1}$, respectively (Figure $2 \mathrm{~B}, 2 \mathrm{C}$ and $2 \mathrm{D}$ ). This increase, according to Bezerra Neto et al. (2014), is due, in part, to the greater availability of nutrients released by green manure, as well as by the synchrony in which these elements are released and absorbed by the plant during the crop cycle. Favacho et al. (2017) studying the productive efficiency of the carrot and cowpea intercropping from green manure and spatial arrangements, found similar results regarding the total and commercial productivity of the carrot and long and medium roots, when greater amounts of green manure from $C$. procera were incorporated. These results were superior to those obtained by Bezerra Neto et al. (2014), where the maximum productivity total, commercial, and long root productivities were investigated in the agroeconomic performance of carrot when using different Merremia aegyptia doses as green manure and found maximum values of $32.11,33.02$, and $18.29 \mathrm{t} \mathrm{ha}^{-1}$, respectively. 
A

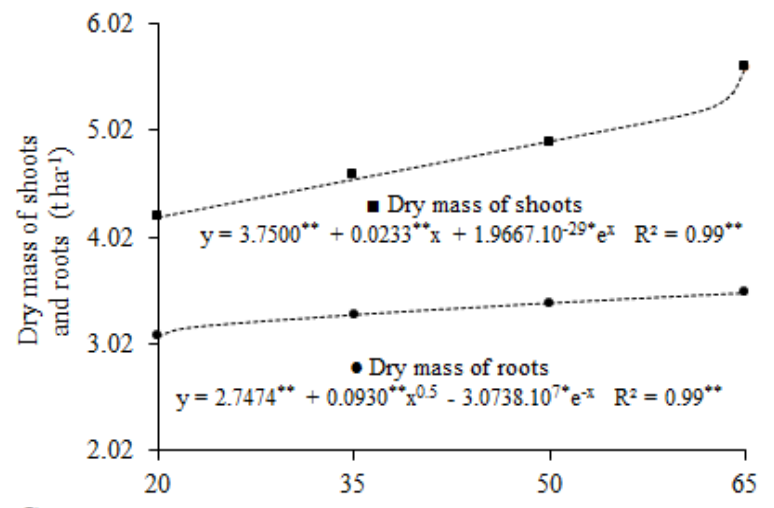

C

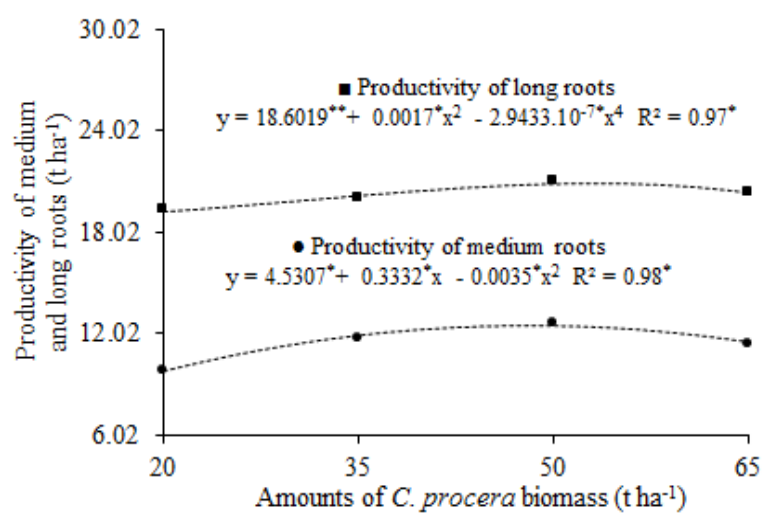

B

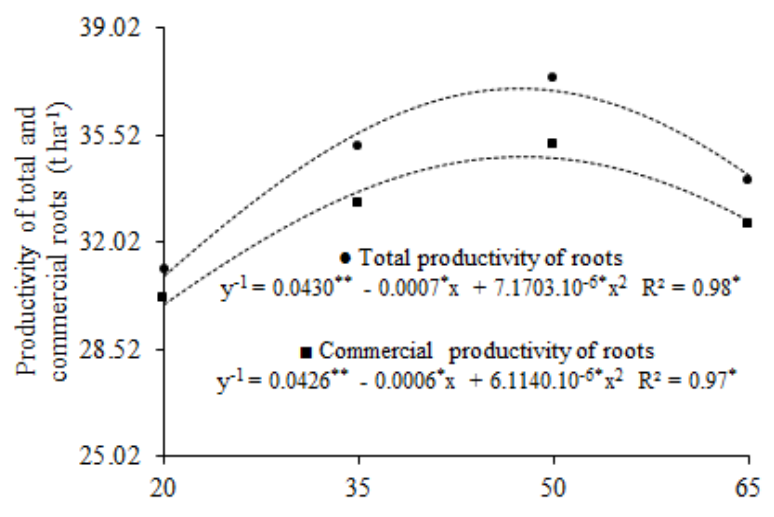

D

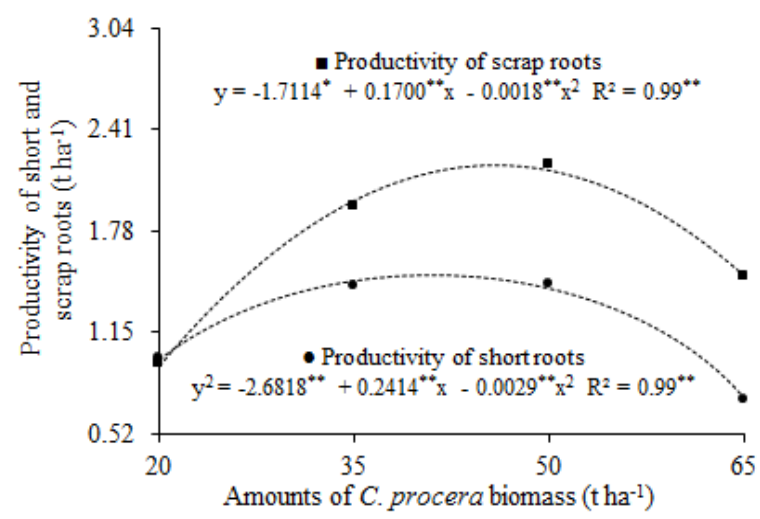

Figure 2. Mean dry mass of shoots and roots (A), total and commercial productivity of roots (B), productivity of medium and long roots (C), and productivity of short and scrap roots (D) of carrot as a function of the amounts of C. procera biomass incorporated into the soil.

Another factor that may have contributed to increased carrot productivity is improved physical, chemical, and biological properties of the soil resulting from the green manure's influence. This because the green manuring increases soil organic matter, improves soil structure, and increases moisture storing capacity in addition to increasing nutrient availability for the crops (BATISTA et al., 2012).

However, the decreases in the carrot productivities after maximum points can be explained by the Maximum Law, where the excess of one nutrient in the soil can cause toxic effects and/ or decrease the efficiency of others, thus reducing agricultural production (ALMEIDA et al., 2015).

\section{Economic efficiency indicators}

Based on a joint analysis of the carrot economic efficiency indicators, there were no significant interactions between growing seasons and C. procera treatments for any of the indicators (Table 4). Gross income, net income, rate of return, and profit margin were all greater in the first growing season (Table 4).

The economic indicators were fit to the amounts of $C$. procera biomass added to the soil with polynomial functions. Maximum gross income, net income, rate of return, and profit margin were $\mathrm{R} \$$ $62,704.94 \mathrm{ha}^{-1}, \mathrm{R} \$ 33,744.07 \mathrm{ha}^{-1}, 2.27$, and $56.63 \%$ with $C$. procera biomass added to the soil at amounts of 47.60, 42.81, 31.69, and 31.85 $\mathrm{t} \mathrm{ha}^{-1}$ (Figure 3).

Greater economic efficiency in carrot cultivation was achieved in the first growing season (2017) when gross income, net income, rate of return, and profit margin obtained their maximum optimized values. This greater efficiency was entirely related to the greater commercial yield of carrot roots during this growing season, which translated into economic efficiency. Greater efficiency in the first season was related to the better soil nutritional conditions and also to the $\mathrm{pH}$ of the soil when compared with of the second growing season, as it was lower, thus facilitating greater absorption of some nutrients by the carrot, consequently providing greater productivity. The mean values of MEE treatments for all carrot indicators differed from those of control treatment (Table 4). In the economic indicators (gross and net income, rate of return and profit magin), the mean values of MEEs were, respectively, 1.7, 1.5, 1.3 and 1.3 times the mean value of control treatment (Table 4). 
Table 4. F values and means for gross income (GI), net income (NI), rate of return (RR) and profit margin (PM) of carrot over two growing seasons and for the control treatment and the maximum economic efficiency treatment (MEE).

\begin{tabular}{|c|c|c|c|c|}
\hline Sources of variation & $\begin{array}{c}\text { GI } \\
\left(\mathrm{R} \$ \mathrm{ha}^{-1}\right) \\
\end{array}$ & $\begin{array}{c}\mathrm{NI} \\
\left(\mathrm{R} \$ \mathrm{ha}^{-1}\right) \\
\end{array}$ & RR & $\begin{array}{l}\mathrm{PM} \\
(\%) \\
\end{array}$ \\
\hline (Blocks/Seasons) & $1.65^{\mathrm{ns}}$ & $1.65^{\mathrm{ns}}$ & $1.38^{\mathrm{ns}}$ & $1.06^{\mathrm{ns}}$ \\
\hline Growing seasons (S) & $51.56^{* *}$ & $48.86^{* *}$ & $17.18^{* *}$ & $6.35^{*}$ \\
\hline $\begin{array}{c}\text { Amounts of } C \text {. procera } \\
\text { (A) }\end{array}$ & $28.67^{* *}$ & $9.81^{* *}$ & $16.53^{* *}$ & $6.91^{* *}$ \\
\hline $\mathrm{S} \times \mathrm{A}$ & $0.49^{\mathrm{ns}}$ & $0.47^{\mathrm{ns}}$ & $2.25^{\text {ns }}$ & $1.94^{\mathrm{ns}}$ \\
\hline Control vs factorial & $6.16^{*}$ & $8.85^{* *}$ & $30.51^{* *}$ & $16.14^{* *}$ \\
\hline CV $(\%)$ & 9.81 & 18.96 & 10.14 & 11.19 \\
\hline \multicolumn{5}{|l|}{$\begin{array}{c}\text { Growing } \\
\text { seasons }\end{array}$} \\
\hline 1 & $60,528.00 \mathrm{a}^{\dagger}$ & $33,841.00 \mathrm{a}$ & $2.12 \mathrm{a}$ & $51.55 \mathrm{a}$ \\
\hline 2 & $49,467.00 \mathrm{~b}$ & $23,084.00 \mathrm{~b}$ & $1.89 \mathrm{~b}$ & $45.99 \mathrm{~b}$ \\
\hline \multicolumn{5}{|l|}{ Comparison treatments } \\
\hline Control & $38,045.00 \mathrm{~b}$ & $21,992.00 \mathrm{~b}$ & $1.78 \mathrm{~b}$ & $44.94 \mathrm{~b}$ \\
\hline MEE treatment & $62,704.94 \mathrm{a}$ & $33,744.07 \mathrm{a}$ & $2.27 \mathrm{a}$ & $56.63 \mathrm{a}$ \\
\hline
\end{tabular}

$* *=\mathrm{P}<0.01 ; *=\mathrm{P}<0.05 ; \mathrm{ns}=\mathrm{P} \geq 0.05 .{ }^{\dagger}$ Means followed by different lowercase letters in a column differ statistically from each other according to Tukey’s post-hoc tests at the $5 \%$ probability level.

A

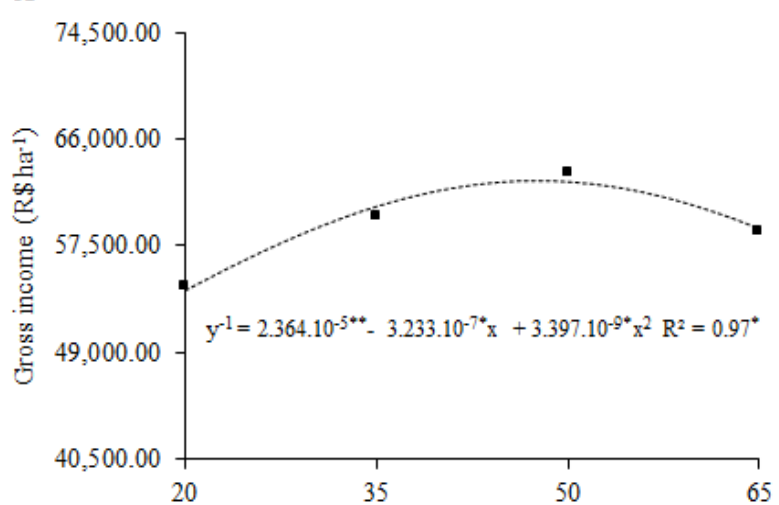

C

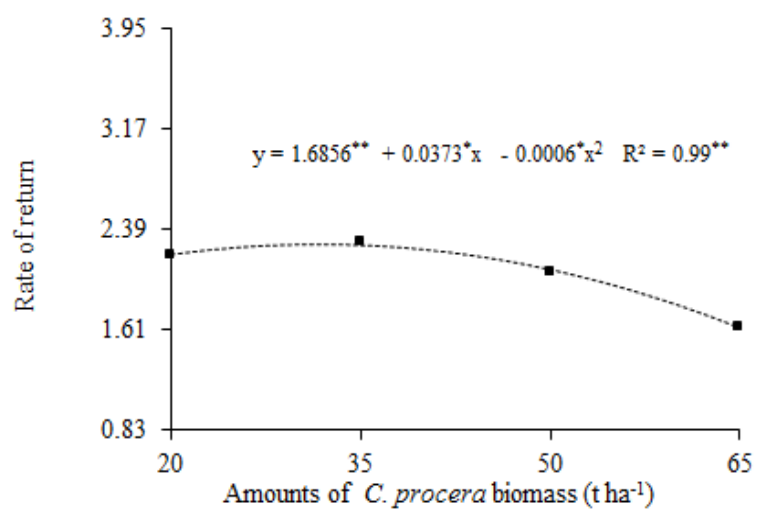

B

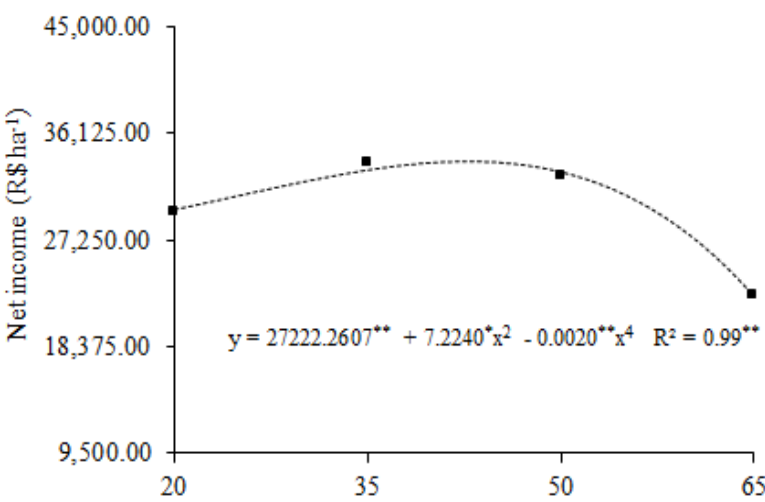

D

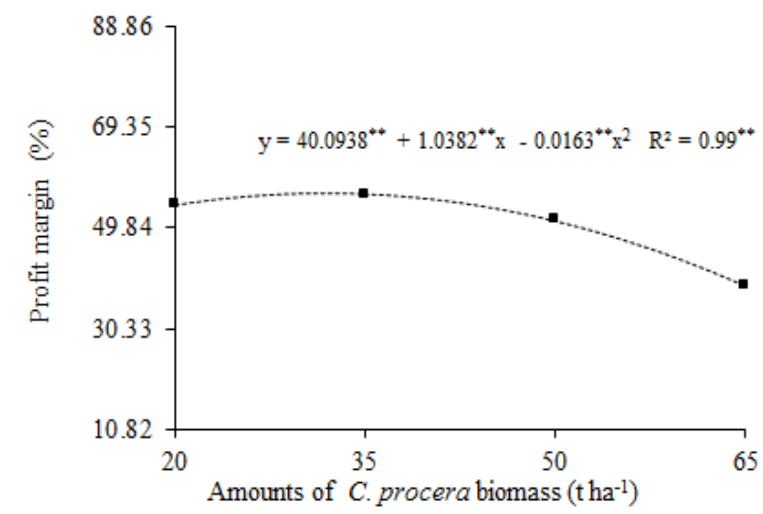

Figure 3. Mean gross income (A), net income (B), rate of return (C), and profit margin (D) of carrot as a function of the amounts of $C$. procera biomass incorporated into the soil.

The high $\mathrm{Na}^{+}$content in the soil in the second growing season may have negatively influenced the yield of carrot roots since carrots are a glycophyte plant that is sensitive to soil salinity. When the soil solution has a high salt content, the growth rate, leaf expansion, and primary carbon metabolism of many crops are adversely affected due to osmotic effects, water deficits, ion toxicity, or nutritional imbalances 
(DIAS et al., 2016)

High concentrations of sodium and chloride ions in the soil solution reduce the osmotic potential, exacerbate nutritional imbalances, and inhibit the absorption of other cations by plants (SILVA et al., 2000). In soils with high levels of sodium in the soil solution, water retention forces increase due to osmotic effects and reduce water absorption by plants (DIAS et al., 2016). Excess soluble salts create greater osmotic pressure that can reach a level where plants are no longer able to compensate with compatible solutes create the cellular osmotic pressure necessary to overcome the soil osmotic pressure, and consequently, the plant is unable to absorb water, even in moist soil (DIAS et al., 2016; SILVA et al., 2000).

The greatest gross income, net income, rate of return, and profit margin were observed with $C$. procera biomass added to the soil at rates of $47.60,42.81,31.69$, and $31.85 \mathrm{t} \mathrm{ha}^{-1}$, respectively. These results were due to carrot responding very well to green manuring with $C$. procera. These values indicate that the productive capacity of carrot obtained when $C$. procera biomass was used as a green manure translated into economic efficiency.

Net income was optimized (RS 33,744.07 ha ${ }^{-1}$ ) when $C$. procera biomass was added at $42.81 \mathrm{t} \mathrm{ha}^{-1}$. Green manuring with $C$. procera was an economically viable fertilization method for carrot cultivation. A previous report indicates that net income is the economic indicator that best expresses the economic value of this system of cultivation since it deducts the costs of production (BEZERRA NETO et al., 2012).

Although the greatest commercial carrot root productivity was achieved when $C$. procera biomass was added at $47.60 \mathrm{t} \mathrm{ha}^{-1}$, in economic terms productivity was greatest when $C$. procera was added at $42.81 \mathrm{t} \mathrm{ha}^{-1}$. This difference in the amount of green manure to be applied is due to the production costs embedded in achieving this maximum productivity.

In general, it can be seen that the carrot fertilization with $C$. procera was highly efficient when compared to the control treatment (without fertilization).

\section{CONCLUSIONS}

The fertilization of carrot to obtain maximum agronomic efficiency (commercial productivity) was made possible with the incorporation into the soil of the amount of $47.60 \mathrm{t} \mathrm{ha}^{-1}$ of $C$. procera optimized dry biomass. The maximum agro-economic efficiency (net income) of carrot cultivation was obtained when the amount of $42.81 \mathrm{t} \mathrm{ha}^{-1}$ of $C$. procera optimized dry biomass incorporated into the soil. The return rates obtained for the carrot cultivation in these optimized quantities were 1.53 and 1.28 , respectively, of those achieved in the control treatment (without fertilization). The use of C. procera as green manure is economically viable to the farmer in the production of carrot.

\section{ACKNOWLEDGEMENTS}

Special thanks are due to the Conselho Nacional de Desenvolvimento Cientifico e Tecnológico $(\mathrm{CNPq})$ for their financial support of this work, and to the Plant Science Research Group of the Universidade Federal Rural do Semi-Árido and Instituto Federal do Ceará-Campus Limoeiro do Norte, which develops technologies for growing vegetable crops on family farms.

\section{REFERENCES}

ALMEIDA, A. E. S. et al. Eficiência agronômica do consórcio alface-rúcula fertilizado com flor-de-seda. Revista Caatinga, 28: 79-85, 2015.

BATISTA, M. A. V. et al. Atributos microbiológicos do solo e produtividade de rabanete influenciados pelo uso de espécies espontâneas. Horticultura Brasileira, 31: 587-594, 2013.

BATISTA, M. A. V. et al. Efeito de diferentes fontes de adubação sobre a produção de alface no município de Iguatu-CE. Revista Caatinga, 25: 8$11,2012$.

BEZERRA NETO, F. et al. Otimização agroeconômica da cenoura fertilizada com diferentes doses de jitirana. Revista Ciência Agronômica, 45: 305-311, 2014.

BEZERRA NETO, F. et al. Assessment of agroeconomic indices in polycultures of lettuce, rocket and carrot through uni - and multivariate approaches in semi-arid Brazil. Ecological Indicators, 14: 11-17, 2012.

BONFIM-SILVA, E. M. et al. Produção e morfologia da leguminosa java submetida a adubação fosfatada. Enciclopédia Biosfera, 7: 1-10, 2011.

BRASIL, E. C.; NASCIMENTO, E. V. S. Influência de calcário e fósforo no desenvolvimento e produção de variedades de maracujazeiro-amarelo. Revista Brasileira de Fruticultura, 32: 892-902, 2010.

DIAS N. S. et al. Efeitos dos sais na planta e tolerância das culturas à salinidade. In: GHEYI, H. R. et al. (Eds.). Manejo da salinidade na agricultura: Estudos básicos e aplicados. $2^{\mathrm{a}} \mathrm{ed}$. 
Fortaleza, CE: INCTSal, 2016. p. 151-161.

EMBRAPA HORTALIÇAS - Empresa Brasileira de Pesquisa Agropecuária. Sistemas de Produção. 5. ed. Brasília, DF: Versão Eletrônica, 2008. 150 p.

EMPARN - Empresa de Pesquisa Agropecuária do Rio Grande Do Norte. Armazenamento de Forragens para a agricultura familiar. Natal, RN: EMPARN, 2004. 38 p.

FAVACHO, F. S. et al. Eficiência produtiva e econômica do consórcio de cenoura $\mathrm{x}$ caupi proveniente de adubação verde e arranjos espaciais. Revista Ciência Agronômica, 48: 337-346, 2017.

FERREIRA, D. F. Sisvar: a computer statistical analysis system. Ciência e Agrotecnologia, 35: 1039-1042, 2011.

JANDEL SCIENTIFIC. Table Curve: curve fitting software. Corte Madera, CA: Jandel Scientific, 1991. $280 \mathrm{p}$.

KROLOW, R. H. et al. Efeito do fósforo e do potássio sobre o desenvolvimento e a nodulação de três leguminosas anuais de estação fria. Revista Brasileira de Zootecnia, 33: 2224-2230, 2004.

LANA, M. M.; VIEIRA, J. V. Fisiologia e manuseio pós-colheita de cenoura. Brasília, DF: Embrapa Hortaliças, 2000. 16 p.

LINHARES, P. C. F. et al. Quantidades e tempos de decomposição da jitirana no desempenho agronômico do coentro. Ciência Rural, 42: 243-248, 2012.

MARTINS, B. N. M. et al. Productivity and economic viability of carrot fertilized with Calotropis procera in different growing seasons. Journal of Experimental Agriculture International, 20: 1-13, 2018.

NUNES, R. L. C. et al. Agro-economic responsiveness of radish associations with cowpea in the presence of different amounts of Calotropis procera, spatial arrangements and agricultural crops. Ciência e Agrotecnologia, 42: 350-363, 2018.

OLIVEIRA, F. L. et al. Produção de fitomassa, acúmulo de nutrientes e decomposição de leguminosas utilizadas para adubação verde. Revista Brasileira de Ciências Agrárias, 5: 503-508, 2010.

PIMENTEL-GOMES, F.; GARCIA, C. H. Estatística aplicada a experimentos agronômicos e florestais. Piracicaba, SP: FEALQ, 2002. 309 p.
RÊGO, L. G. S. et al. Pedogenesis and soil classification of an experimental farm in Mossoró, state of Rio Grande do Norte, Brazil. Revista Caatinga, 29: 1036-1042, 2016.

RIBEIRO, J. R. S. et al. Production efficiency in cultivar combinations of beet and cowpea in the semi -arid environment. Horticultura Brasileira, 38: 451 $-457,2020$.

SEDIYAMA, M. A. N.; SANTOS I. C.; LIMA P. C. Cultivo de hortaliças no sistema orgânico. Revista Ceres, 61: 829-837, 2014.

SILVA, F. A. M. et al. Efeito do estresse salino sobre a nutrição mineral e o crescimento de mudas de Aroeira (Myracrodruon urundeuva) cultivadas em solução nutritiva. Cerne, 6: 52-59, 2000.

SILVA, J. N. et al. Combinations of coriander and salad rocket cultivars in bicropping systems intercropped with carrot cultivars. Revista Caatinga, 30: 125-135, 2017.

SILVA, M. L. et al. Produção de cenoura fertilizada com flor-de-seda (Calotropis procera (Ait.) R.Br.). Revista Ciência Agronômica, 44: 732-740, 2013.

SOUZA, D. M. et al. Desempenho agroeconômico da associação beterraba com caupi-hortaliça em diferentes quantidades de jitirana. Revista Brasileira de Engenharia Agrícola e Ambiental, 22: 194-199, 2018

SOUZA, E. G. F. et al. Rentabilidade da rúcula fertilizada com biomassa de flor-de-seda em função da época de cultivo. Revista Caatinga, 28: 65-77, 2015 .

VIEIRA, F. A. et al. Technical-economic efficiency of the yield of green grains of cowpea fertilized with roostertree. Revista Caatinga, v. 31, n. 2, p. 504$510,2018$. 